\begin{tabular}{|c|c|c|}
\hline & Benha Veterinary Medical Journal & i) \\
\hline $\begin{array}{l}\text { Official Journal Issued by } \\
\text { Faculty of } \\
\text { Veterinary Medicine }\end{array}$ & Journal homepage: https://bvmj.journals.ekb.eg/ & $\begin{array}{c}=15= \\
\text { Since } 1990\end{array}$ \\
\hline
\end{tabular}

Original Paper

\title{
Identification of Some Biological Hazards in Some Meat Products
}

\author{
Wafaa Hazaa $^{1}$, Fahim Shaltout ${ }^{1}$, Mohamed El-Shater ${ }^{2}$
}

${ }^{1}$ Department of Food Hygiene, Faculty of Veterinary Medicine, Benha University, Egypt

${ }^{2}$ Department of Food Hygiene, Animal Health Research Institute, Dokki, Giza, Egypt

\section{ARTICLE INFO}

\begin{tabular}{l}
\hline Keywords \\
B. cereus \\
Biological hazards \\
Meat products \\
S. aureus \\
\hline
\end{tabular}

Received 04/08/2019

Accepted 05/10/2019

Available On-Line

$12 / 05 / 2020$

\begin{abstract}
The biological hazards are by far the primary food safety concern in which, contamination of meat product with biological hazards rendering them unfit for human consumption and considered as a global health issue. This study aimed to determine the safety of some meat products in which sixty samples of processed meat product represented by minced meat, beef burger, sausages and luncheon (15 samples of each) that were randomly gathered from distinct supermarkets and shops at Benha City at Kalubia Governorate, Egypt to determine occurrence of Bacillus cereus and Staph aureus microorganisms as a biological hazards. The attained results revealed that B. cereus and Staph. aureus could be isolated from the ehecked samples of minced meat, beef burger, sausage and beef luncheon with the incidences of $13.3 \%$ and $20 \%, 33.3 \%$ and $46.7 \%, 46.7 \%$ and $53.3 \%$, and $26.7 \%$ and $33.3 \%$ and with mean values of $5.26 \times 10^{2} \pm 0.81 \times 10^{2}$ and $7.12 \times 10^{2} \pm 1.15 \times 10^{2}, 2.19 \times 10^{3} \pm 0.43 \times 10^{3}$ and $3.96 \times 10^{3}$ $\pm 0.63 \times 10^{3}, 8.47 \times 10^{3} \pm 1.79 \times 10^{3}$ and $9.35 \times 10^{3} \pm 2.10 \times 10^{3}$, and $1.09 \times 10^{3} \pm 0.25 \times 10^{3}$ and $1.48 \times 10^{3} \pm 0.31 \times 10^{3}(\mathrm{cfu} / \mathrm{g})$ in the evaluated samples, respectively. The attained results were matched up to the permissible limits of Staph. aureus count stipulated by Egyptian Organization for Standardization to assess their acceptability and it was recommended to set up permissible limits of Bacillus cereus count in Egyptian Standards for such products.
\end{abstract}

\section{INTRODUCTION}

Meat products are achieving common popularity as seeing that it easily rapidly prepared meat meals which can solve the matter of the shortage of highly cost fresh meat that isn't within the reach of enormous numbers of low-income families (Shawish and Tarabees, 2017). Consequently, it considered the best selection in resolving human nutritional issues, but it may harbor hazards to human health through the long chain of preparation, processing, distribution, storage, and retailing. The hazards that compromise the safety of meat products are of biological, chemical, and/or physical nature (Sofos, 2014).

Biological hazards are the greatest concern foodborne hazards that embody an infective bacterium, viral pathogens, and parasites. Bacterial hazards are that the most typical reason behind food-borne illness (WHO, 2007). Among of the principal pathogens which can be transmitted through meat products are Bacillus cereus and Staph. aureus that were frequently implicated in food-borne illness and should be considered in assessing hazards to human health from the consumption of meat products (Xavier et al., 2014).

Bacillus cereus group ubiquitously distributed in the environment, mainly owing to their resistant spores, therefore it is not surprising that B. cereus contaminate various types of final food products
(Ceuppens et al., 2010). The major factors that make $B$. cereus a potential hazard to food processing are its abilities to form thermoduric endospore, to grow and survive at refrigeration temperature and toxin production (Okanlawon et al., 2010). Mainly, it has been accused to cause two distinct patterns of foodborne illness that manifested by emetic syndrome and diarrheal syndrome (Drobniewski, 1993).

Also, Staphylococcus aureus is believed to be an important cause of food intoxication throughout the world that contaminate several foods including processed meat products and produce several types of enterotoxins (EL-Hadedey and Abu-EL-Nour, 2012). If meat product is temperature abused, this pathogen is able to proliferate and produce heat-resistant enterotoxins (Sofos, 2014) that were notified to be a potential biological threat because of their stability at high temperature $\left(100^{\circ} \mathrm{C}\right.$ for $1 \mathrm{hr}$.) and their ability to incapacitate persons for several days to two weeks (Bhatia and Zahoor,2007).

Therefore, the current study was planned out to determine the presence of such of biological hazards in some of meat products and evaluate the safety and acceptability of such products for human consumption according to the stipulated Egyptian standards

\section{MATERIAL AND METHODS}

\subsection{Preparation of samples (APHA, 2001):}

\footnotetext{
* Corresponding author Prof. Fahim Shaltout. Department of Bacteriology, Faculty of Veterinary Medicine, Benha University
} 
Twenty five grams of the meat products specimens were taken under aseptic condition to sterile stomacher bag then $225 \mathrm{ml}$ sterile $0.1 \%$ peptone water were added, then homogenized at stomacher for 2 minutes, the mixture was allowed to settled, for 5 minutes at room temperature .The contents were transferred in to sterile flask, thoroughly mixed, $1 \mathrm{ml}$ was transferred in to separate sterile test tube containing $9 \mathrm{ml}$ sterile $0.1 \%$ peptone water, from which tenth-fold serial dilutions were prepared. The prepared samples were subjected to the following examination:

2.2. Determination of total B. cereus count using (PEMBA agar) (Harrigan and McCane, 1976):

At which typical colonies of $B$. cereus characterized by blue turquoise color and surrounded by a halo zone of white precipitation.

Isolation and identification of B. cereus according to (Koneman et al. 1975).

\subsection{Determination of Staphylococci and Staph.} aureus count using Baired Parker agar (FDA, 2001).

The developed colonies (shiny black colonies) were enumerated and total staphylococcal count/g was calculated. The suspected colonies of Staph. aureus appear as black, shiny, circular, smooth, convex with narrow white margin and surrounded by a clear zone extending into opaque medium were enumerated and Staphylococcus aureus count/g was calculated.

\subsection{Isolation of Staph. aureus according to (Quinn et al. 2002).}

Suspected Staph. aureus colonies were picked up, purified and sub-cultured on BHI agar for morphological, biochemical, and serological identification.

\section{RESULTS}

It is apparent from the results tabulated in table (1) that, B. cereus was isolated from the inspected meat products samples with incidences of $13.3 \%, 33.3 \%$, $46.7 \%$ and $26.7 \%$ \& with mean values of $5.26 \times 10^{2} \pm$ $0.81 \times 10^{2}, 2.19 \times 10^{3} \pm 0.43 \times 10^{3}, 8.47 \times 10^{3} \pm 1.79 \times 10^{3}$ and $1.09 \times 10^{3} \pm 0.25 \times 10^{3}(\mathrm{cfu} / \mathrm{g})$ in minced meat, beef burger, sausage and luncheon, respectively. Also, there was a highly significant difference between the examined products based on $B$. cereus counts $(\mathrm{P}<0.01)$ by ANOVA analysis.

Table 1 Statistical analytical results of Bacillus cereus counts/g in the examined samples of meat products $(\mathrm{n}=15)$.

\begin{tabular}{|c|c|c|c|c|c|}
\hline \multirow{2}{*}{$\begin{array}{l}\text { Samples } \\
\text { Samples }\end{array}$} & \multicolumn{2}{|c|}{ +ve samples } & \multirow{2}{*}{$\begin{array}{l}\text { Min } \\
\text { Min }\end{array}$} & \multirow{2}{*}{$\begin{array}{l}\text { Max } \\
\text { Max }\end{array}$} & \multirow{2}{*}{$\begin{array}{l}\text { Mean } \pm \text { S.E.E } \\
\text { Mean } \pm \text { S.E. }\end{array}$} \\
\hline & NO & $\%$ & & & \\
\hline M. meat & 2 & 13.3 & $1.0 \times 10^{2}$ & $1.2 \times 10^{3}$ & $5.26 \times 10^{2} \pm 0.81 \times 10^{2++}$ \\
\hline Beef burger & 5 & 33.3 & $2.0 \times 10^{2}$ & $6.5 \times 10^{3}$ & $2.19 \times 10^{3} \pm 0.43 \times 10^{3++}$ \\
\hline Sausage & 7 & 46.7 & $5.0 \times 10^{2}$ & $3.7 \times 10^{4}$ & $8.47 \times 10^{3} \pm 1.79 \times 10^{3++}$ \\
\hline Luncheon & 4 & 26.7 & $1.0 \times 10^{2}$ & $2.9 \times 10^{3}$ & $1.09 \times 10^{3} \pm 0.25 \times 10^{3++}$ \\
\hline
\end{tabular}

The achieved findings in table (2) demonstrated that the mean values of Staphylococci counts/g in the studied minced meat, beef burger, sausage and beef luncheon samples were $1.21 \times 10^{3} \pm 0.18 \times 10^{3}$, $5.14 \times 10^{3} \pm \quad 0.76 \times 10^{3}, \quad 1.86 \times 10^{4} \pm 0.31 \times 10^{4}$ and
$2.57 \times 10^{3} \pm 0.42 \times 10^{3}(\mathrm{cfu} / \mathrm{g})$, respectively. While the findings recorded in table (3) revealed that the rates of occurrence of Staph. aureus in the evaluated samples of minced meat, beef burger, sausage and luncheon were $20 \%, 46.7 \%, 53.3 \%$ and $33.3 \%$ with mean values of $7.12 \times 10^{2} \pm 1.15 \times 10^{2}, \quad 3.96 \times 10^{3} \pm 0.63 \times 10^{3}$, $9.35 \times 10^{3} \pm 2.10 \times 10^{3}$ and $1.48 \times 10^{3} \pm 0.31 \times 10^{3} \mathrm{cfu} / \mathrm{g}$, respectively. Also, there is a highly significant difference $(P<0.01)$ of Staph. aureus count between the examined products. Furthermore, 38.3\% (23/60 samples) of the studied samples were unaccepted based on their contamination with Staph. aureus according to ES (2005) as declared in table (4).

Table 2 Statistical analytical results of total Staphylococci counts/g in the examined samples of meat products $(n=15)$.

\begin{tabular}{|c|c|c|c|}
\hline Samples & Min & Max & Mean \pm S.E ${ }^{*}$ \\
\hline Minced meat & $3.0 \times 10^{2}$ & $4.6 \times 10^{3}$ & $1.21 \times 10^{3} \pm 0.18 \times 10^{3++}$ \\
\hline Beef burger & $5.0 \times 10^{2}$ & $9.7 \times 10^{3}$ & $5.14 \times 10^{3} \pm 0.76 \times 10^{3++}$ \\
\hline Sausage & $7.0 \times 10^{2}$ & $5.2 \times 10^{4}$ & $1.86 \times 10^{4} \pm 0.31 \times 10^{4++}$ \\
\hline Luncheon & $2.0 \times 10^{2}$ & $6.5 \times 10^{3}$ & $2.57 \times 10^{3} \pm 0.42 \times 10^{3++}$ \\
\hline
\end{tabular}

Table 3 statistical analytical results of total Staph. aureus count/g in the examined samples of meat products $(\mathrm{n}=15)$

\begin{tabular}{|c|c|c|c|c|c|}
\hline \multirow{2}{*}{$\begin{array}{l}\text { Samples } \\
\text { Samples }\end{array}$} & \multicolumn{2}{|c|}{ +ve samples } & Min & Max & Mean \pm S.E \\
\hline & NO & $\%$ & Min & Max & Mean \pm S.E $E^{*}$ \\
\hline Minced meat & 3 & 20 & $1.0 \times 10^{2}$ & $2.7 \times 10^{3}$ & $7.12 \times 10^{2} \pm 1.15 \times 10^{2++}$ \\
\hline Beef burger & 7 & 46.7 & $3.0 \times 10^{2}$ & $8.1 \times 10^{3}$ & $3.96 \times 10^{3} \pm 0.63 \times 10^{3++}$ \\
\hline Sausage & 8 & 53.3 & $6.0 \times 10^{2}$ & $3.7 \times 10^{4}$ & $9.35 \times 10^{3} \pm 2.10 \times 10^{3++}$ \\
\hline Luncheon & 5 & 33.3 & $1.0 \times 10^{2}$ & $4.0 \times 10^{3}$ & $1.48 \times 10^{3} \pm 0.31 \times 10^{3++}$ \\
\hline
\end{tabular}

Table 4 Acceptability of the examined samples of meat products based on their contamination with Staph. aureus $(\mathrm{n}=15)$

\begin{tabular}{llllll}
\multicolumn{2}{l}{ based on their contamination with Staph. aureus $(\mathrm{n}=15)$} \\
\hline Samples & Staph. aureus count/g* & \multicolumn{2}{l}{ Accepted } & \multicolumn{2}{c}{ Unaccepted } \\
& Staph. aureus count/g* & No & $\%$ & No & $\%$ \\
\hline Minced meat & $10^{2}$ & 12 & 80 & 3 & 20 \\
Beef burger & $10^{2}$ & 8 & 53.3 & 7 & 46.7 \\
Sausage & $10^{2}$ & 7 & 46.7 & 8 & 53.3 \\
Luncheon & Free & 10 & 66.7 & 5 & 33.3 \\
Total & & 37 & 61.7 & 23 & 38.3
\end{tabular}

*Egyptian Standards "E. S" (2005). No 1694-2005 for minced meat, No 16882005 for beef burger, No 1972-2005 for sausage, and No 1114-2005 for luncheon.

\section{DISCUSSION}

The biological hazards that related to the consumption of different types of meat product could be represented by pathogenic bacteria, viruses and parasites. In general, the presence of the microbial hazards within the meat products is unavoidable as the microorganisms are present on animals and in their surrounding environment (Maricica et al.,2014), besides exposure to contamination with microorganisms from different sources during preparation and processing which differed according to the method of manufacture, the quality of nonmeat added ingredients and contamination level during the processing chain, packaging and storage among this microorganism are B. cereus and Staph. aureus that constitute hazards to the consumer and are frequently implicated in food-borne illness (Xavier et $a l ., 2014)$. The existing study revealed that $B$. cereus could be isolated at percentage of $30 \%$ (18/60) from the overall studied samples of various types meat products in which, the highest incidence for isolation 
of $B$. cereus was recorded in the assessed sausage samples $(46.7 \%)$ followed by burger samples $(33.3 \%)$, while the lowest incidence was recorded in minced meat samples $(13.3 \%)$ followed by luncheon samples (26.7\%) as shown in table (1). The obtained findings were nearly equivalent to that achieved by (Emara, 2014) who declared that the incidence of B. cereus in studied samples of minced meat was $(13 \%)$ but disagreed with higher incidence recorded by (Heikal et al., 2006) (65\%) for beef burger samples. Generally, presence $B$. cereus in meat products is probably due to heat resistance of $B$. cereus spores that enable this microorganism to survive in harsh environments besides improper storage conditions of the products and inadequate cooking (Rather et al., 2011) Moreover, the ingredients such as spices, seasonings, and protein supplements which added during processing, have been found to contain $B$. cereus (TeGiffel et al., 1999).

Also, the achieved findings stated that the mean values of $B$. cereus counts $(\mathrm{cfu} / \mathrm{g})$ in the evaluated samples were $5.26 \times 10^{2} \pm 0.81 \times 10^{2}, \quad 2.19 \times 10^{3} \pm$ $0.43 \times 10^{3}, \quad 8.47 \times 10^{3} \pm 1.79 \times 10^{3}$ and $1.09 \times 10^{3} \pm$ $0.25 \times 10^{3}$ for samples of minced meat, burger, sausage and luncheon, respectively. These results were exceeding those obtained by (Ibrahim-Hemmat et al. 2014) $\left(1.03 \times 10^{3} \mathrm{cfu} / \mathrm{g}\right)$ in sausage samples but it came in agreement with (Abd El-Wahaab-Shimaa, 2018) $\left(2.35 \times 10^{3} \mathrm{cfu} / \mathrm{g}\right)$ in beef burger samples. Generally during processing, handling and storage absence or lack of hygienic measures, besides, the abuse of storage temperature and improper cooking allow the spore of B. cereus to germinate and multiply which considered the probable reason behind the increasing of B. cereus count (Bashir et al., 2017). This microorganism causes two forms of illness syndrome, emetic syndrome that' san intoxication caused by intake of toxin called cereulide that's preformed within the food throughout growth of $B$. cereus and has a short incubation period with symptoms of nausea, vomit ion and abdominal cramping occur at intervals $1-5 \mathrm{~h}$ of intake, with recovery usually within $6-24 \mathrm{~h}$. Other than that the diarrheal syndrome which caused by enterotoxins created by $B$. cereus inside the body with period regarding about $8-16 \mathrm{~h}$ before onset of illness that typically lasts for $12-24 \mathrm{~h}$, whereas it can continue for numerous days with symptoms of nausea, abdominal cramps and watery diarrhea (Senesi and Ghelardi, 2010). Furthermore, according to ANOVA analysis, the differences between the examined meat products samples were highly significant $(\mathrm{p}<0.01)$ as shown in table (1), this could be attributed to difference of the ingredients and steps involved in the processing of the products (Hefnawy and Youssef, 1984).

Staphylococcus spp. are considered as an ordinary environmental microorganism and therefore it could be found within the food in consequence of cross contamination (Mosupy and Holy, 1999). Presence of Staphylococci in meat products is taken into consideration as a decent index for poor hygiene and poor manufacturing practices (Musa, 2002). Results achieved in table (2) stated that the total Staphylococci counts in the investigated samples of meat product ranged from $3.0 \times 10^{2}$ to $4.6 \times 10^{3}$ with an average value of $1.21 \times 10^{3} \pm 0.18 \times 10^{3}$ for minced meat, $5.0 \times 10^{2}$ to $9.7 \times 10^{3}$ with an average value of $5.14 \times 10^{3} \pm 0.76 \times 10^{3} \mathrm{cfu} / \mathrm{g}$ for beef burger, $7.0 \times 10^{2}$ to $5.2 \times 10^{4}$ with an average value of $1.86 \times 10^{4} \pm 0.31 \times 10^{4}$ for sausage and $2.0 \times 10^{2}$ to $6.5 \times 10^{3}$ with an average value of $2.57 \times 10^{3} \pm 0.42 \times 10^{3}$ for luncheon. Also, According to ANOVA analysis, there were a highly significant differences $(P<0.01)$ in Staphylococci counts between the investigated products as shown in table (2).The current outcome of minced meat was lower than that obtained by Talaat -Nagwa (Nagwa, $2009)\left(6.92 \times 10^{6} \pm 2.36 \times 10^{6}\right)$ while, the result of burger was nearly similar to that achieved by BadrSarah (2018) (4.07 x10 $\left.0^{3} \mathrm{cfu} / \mathrm{g}\right)$.

There are many types of Staphylococci, but most infections complaints are caused by Staph. aureus which is considered as one amongst the most common reasons of confirmed food poisoning infections throughout the world (Acco et al., 2003). In general, contamination with Staph. aureus is an important hazard index in evaluation of safety of the product (Jyhshiun et al., 2009). It is apparent from the recorded findings in table (3) that the maximum incidence for Staph. aureus isolation from the assessed meat product samples was recorded in sausage samples $(53.3 \%)$ followed by beef burger samples $(46.7 \%)$, while the minimum incidence was recorded in the samples of minced meat (20\%)followed by luncheon meat samples (33.3\%).Higher incidences were recorded by LabanReham (2018) $(70 \%)$ \& (60\%) for minced meat\& luncheon. Meanwhile lower incidences were obtained by Shaltout et al. (2016) (20\%) in sausage and (8.6\%) in luncheon. Also, it was similar to that recorded by Armany et al. (2016) (20\%) in minced meat. The existence of Staph. aureus in meat products is considered a trustworthy index of improper handling during processing therefore, total Staph. aureus count may be taken as indicator of hygienic situation in which these products are produced or manufactured (Nadim -Samaa 2016). Also, the obtained consequences demonstrated that the average value of Staph. aureus count in the investigated samples of minced meat, beef burger, sausage and luncheon was $7.12 \times 10^{2} \pm \quad 1.15 \times 10^{2}, \quad 3.96 \times 10^{3} \pm \quad 0.63 \times 10^{3}$, $9.35 \times 10^{3} \pm 2.10 \times 10^{3}$ and $1.48 \times 10^{3} \pm 0.31 \times 10^{3} \mathrm{cfu} / \mathrm{g}$, respectively. And regarding to Staph. aureus count there is a highly significant variation between the studied $\operatorname{product}(P<0.01)$. This findings were agree to some extent to those obtained by Morshdy et al. (2013) $4.3 \times 10^{2} \mathrm{cfu} / \mathrm{g}$ ) for minced meat and Saleh et al. (2010) $\left(1.14 \times 10^{3} \mathrm{cfu} / \mathrm{g}\right)$ for luncheon samples. While disagreed with higher results obtained by Laban-Reham (2018) $\left(7.5 \times 10^{4} \mathrm{cfu} / \mathrm{g}\right)$ for beef burger and Ibrahim -Shimaa (2016) $\left(4.92 \times 10^{6} \mathrm{cfu} / \mathrm{g}\right)$ for luncheon. And with lower findings indicated by Shalaby and Zaki (2008) who demonstrated that the average count value of Staph. aureus in beef burger was $8.3 \times 10^{2} \mathrm{cfu} / \mathrm{g}$. Generally, the presence of Staph. aureus in meat products is attributed to poor hygiene and handling practices and inadequate refrigeration of foods that have been identified as the main factor contributing to food borne diseases (Schelin et al., 2011). Staphylococcal food intoxication is caused in consequence of ingestion of food contaminated with preformed SE in which the toxic levels of SEs are produced in foods when Staph. aureus concentration exceeds $10^{5} \mathrm{cfu} / \mathrm{ml}$. Actually, less than $1.0 \mu \mathrm{g}$ of the 
toxin in food will induce symptoms of staphylococcal intoxication (Pexara et al., 2010) that include abdominal pain, diarrhea, and vomiting, generally the severity of the illness depends on the amount of food ingested, the amount of toxin in ingested food and the general health of the victim (Schelin et al., 2011). Complying the obtained findings to the maximum permissible level of Staph. aureus count stipulated by ES (2005) (that was $\left(10^{2}\right)$ in frozen minced meat, beef burger and sausage product and free in luncheon) where in the registered results in table (4) illustrated that $38.3 \%(23 / 60)$ of the whole examined meat products samples were unaccepted which including $20 \%, 46.7 \%, 53.3 \%$ and $33.3 \%$ of the assessed samples of minced meat, beef burger, sausage and beef luncheon, respectively.

\section{CONCULOSIONS}

These findings demonstrate that presence of biological hazards in meat products such as $B$. cereus and Staph. aureus is considered a great source of food poisoning illnesses and serious hazardous infections for consumers. An overall the incidence of B. cereus and Staph. aureus in the assessed products regardless of the type of the product was $30 \%$ and $38.3 \%$ that indicate that meat products pose a potential public health threat. In which, sausage samples were the most contaminated types among the examined meat products types followed by beef burger, beef luncheon and minced meat, respectively. Therefore, measures to assure the quality of the raw ingredients besides controlling of the environmental and the hygienic conditions throughout the processing ought to be applied for the offering of fairly safe products. Also, it's recommended to add permissible limits of $B$. cereus in Egyptian Standards for meat products.

\section{REFERENCES}

1. Abd El-Wahaab-Shimaa, A. 2018. Detection of virulence gene of Bacillus cerus in meat products by using multiplex PCR. PhD.V.Sc. Thesis (Meat Hygiene and Control) Fac. Vet. Med. Benha univ. Egypt.

2. Acco, M., Ferreira, F.S., Henriques J.A.P. and Tondo, E. C. 2003. Identification of multiple strains of Staphylococcus aureus colonizing nasal mucosa of food handlers. Inter. J. Food. Microbiol. 20:489-493.

3. APHA "American Public Health Association" 1992.Compendium of methods for the microbiological examination of foods. $3^{\text {rd }}$ Ed. Speck, H.L. (ed.). Washington D.C. APHA.

4. Armany, A.G, Ibrahim-Hemmat, M., Amin-Reham, A. and Ahmed-Hanaa, A. 2016. Detection of foodborne pathogenes in meat products by Polymerase Chain Reaction. Benha Vet. Med. J. 30(1):323-330,

5. Badr-Sarah, M.M. 2018. Follow up of E. coli and Staphylococcus aureus in some locally manufactured meat products. M.V.Sc. Thesis (Meat Hygiene and Control) Fac. Vet. Med. Benha univ. Egypt.

6. Bhatia, A. and Zahoor, S. 2007. Staphylococcus enterotoxins: A review.J. Clinical and Diagnostic Res., (1):188-197.

7. Ceuppens,S.; Boon, N., Rajkovic, A.,Heyndrickx,M.,.Wiele, T.V.D. and Uyttendaele, M. 2010. Quantification methods for B.cereus vegetative cells and spores in gasterointestinal environment. Journal of Mcrobiolgical Methods., 83:202-210.
8. Drobniewski, F.A. 1993. Bacillus cereus and related species. Clin. Microbiol. Rev. 6(4), 324-338.

9. El-Hadedy, D. and Abu El-Nour, S. 2012. Identification of Staphylococcus aureus and Escherichia coli isolated from Egyptian food by conventional and molecular methods. Journal of Genetic Engineering and Biotechnology, 10:129-135.

10. Emara, S.M. 2014. Anaerobic and aerobic microorganisms in human foods. M.V.Sc. Thesis (Microbiology) Fac. Vet. Med. Cairo Univ.

11. ES "Egyptian standards "2005. Egyptian standards for requirements of minced meat No: 1694. Egyptian standards for requirements of beef burger No: 1688 . Egyptian standards for requirements of sausage No: 1972. Egyptian standards for requirements of luncheon meat No: 1114

12. FDA "Food and Drug Administration" 2001.Staphylococcus aureus. Bacteriological analytical manual $.8^{\text {th }}$ Ed. Chapter12.Gaithersburg, Pp.562.

13. Harrigan, W.F and McCane, M.E. 1976. Laboratory methods in food and Dairy microbiology. Academic Press. London, New York, San Francisco, USA.

14. Hefnawy, Y.A. and Youssef, H.H. 1984. Microbiological evaluation of some selected spices. Assuit Vet. Med. J. 13(25): 145-149.

15. Heikal, G.I., Khafagi, N.I.M. and Mostafa, N.Y. 2006. Bacillus cereus in some ready to cook meat products.Benha Vet. Med. J.17 (2):343-350.

16. Ibrahim - Shimaa, M. A.E. 2016. Detection of Staphylococcus aureusclassic enterotoxin genes in some meat products using multiplex PCR. Ph. D. Thesis. (Meat Hygiene) Fac. Vet. Med., Kafr-Elsheikh Univ. Egypt.

17. Ibrahim-Hemmat, M.I., Amani, M.S., Dalia, A.S. and Ghada, A.A. 2014. Demonstration of Aerobic Spore Formers in Some Meat products. Benha Veterinary Medical Journal. 26(2):219-226.

18. Jyhshiun, L., Kuang-Sheng, Y., Hsueh-Tao, L. and Jiun-Horng, L. 2009. Staphylococcus aureus isolated from pork and chicken carcasses in Taiwan: prevalence and antimicrobial susceptibility J. Food Protect. 72(3):608-611.

19. Laban-Reham, A.A. 2018. Detection of methicillin resistant Staphylococcus aureus in some meat products. M.V.Sc. Thesis Department of food control (Meat Hygiene) Faculty of Veterinary Medicine Zagazig University Egypt.

20. Maricica, S., Silvia, S. and Petru, A.2014. Overview of biological hazards associated with the consumption of the meat products. Journal of Agroalimentary Processes and Technologies. 20(2):192-197.

21. Morshdy, A.M., El- Atabany, A.I., Hussein, M. A. and Nasr, M.A.S. 2013. Detection of enterotoxigenic Staphylococcus aureus in some meat products. Assuit Vet. Med. J. 59(137): 100-106.

22. Mosupye, F.M. and Holly, A. 1999. Microbiological quality and safety of ready-to-eat street vended foods in Johannesburg. South Africa. J. Food Protect. 62 11: 1278 .

23. Musa, O.L. and Akande, T.M. 2002. Effect of Health Education Intervention or Food Safety Practice among Food Vendors in Ilorin. J. Med. 5:120 - 124

24. Nadim- Samaa, S. A. 2016. A comparative study on application of PCR and ELISA for detection of pathogens in some meat products with special references to public health. Ph.D. Thesis (Meat Hygiene) Fac. Vet. Med. Benha Univ.

25. Okanlawon, B.M., Ogunbanwo, S.T. and Okunlola, A.O. 2010. Growth of B.cereus isolated from some traditional condiments under different regimens. African J.Biotechnol., 8(14): 2129-2135.

26. Park, Y.B., Kim, J.B., Shin, S.W., Kim, J.C., Cho, S.H., Lee, B.K., Ahn, J., Kim, J.M. and Oh, D.H. 2009. Prevalence, genetic diversity, and antibiotic susceptibility of Bacillus cereus strains isolated from 
rice and cereals collected in Korea. J. Food Prot., 72(3):612-617.

27. Pexara, A., Burrie, L.A. and Govaris, A. 2010. Staphylococcus aureus and Staphylococcal enterotoxins in foodborne diseases. J. The Hellenic Vet. Med. Society 61: 316-322.

28. Quinn, P. J., Markey, B. K., Carter, M. E., Donnelly, W. J. C., Leonard, F. C. and Maguire, D. 2002. Veterinary microbiology and microbial disease. Iowa State Univ. Press, Blackwell Science Ltd, chapters (26-36): 84-96.

29. Rather, M.A., Aulakh, R.S. Gill, J.P.S. and Ghatak, S. 2012. Enterotoxin Gene Profile and Antibiogram of Bacillus Cereus Strains Isolated from Raw Meats and Meat Products. Journal of Food Safety. 32(1): 22-27.

30. Saleh, E.A., Ali, H.A. and Abu-Khadra, A.M. 2010. Detection of some food poisoning microorganisms in some meat products. Alexandria Journal of Veterinary Sciences. 31(1):27-33.

31. Schelin, J., Wallin-Carlquist, N., Cohn, M.T., Lindqvist, R., Barker, G.C. and Rådström, P. 2011. The formation of $\mathrm{S}$. aureus enterotoxin in food environments and advances in risk assessment. Virulence 2(6): 580-592.

32. Shaltout, F.A.E., Maarouf, A.A.A., El-Kewaiey, A.I. and Heweidy, A.Y.A. 2016. Prevalence of some food borne microorganisms in meat and meat products. BVMJ, 31(2): 213:219.

33. Shawish, R. and Tarabees, R. 2017. Prevalence and antimicrobial resistance of Bacillus cereus isolated from beef products in Egypt. Open Veterinary Journal, 7(4): 337-341.

34. Sofos, J.N. 2014. Meat and Meat Products.In: Food Safety Management. Elsevier Inc., Oxford, 119-162.

35. Talaat-Nagwa, W. 2009. Bacteriological and histological evaluation of some meat products. M. V. Sc. (Meat hygiene) Fac. Vet. Med. Kar el-sheikh Univ.

36. Tallent, S. M., Kotewicz, K. M., Strain, E. A. and Bennett, R. W. 2012. Efficient isolation and identification of Bacillus cereus group. U.S. Food and Drug Administration, Center for Food Safety and Applied Nutrition, 5100 Paint Branch Pkwy, College Park, MD 20740, USA. Sandra, 95(2): 446-451.

37. TeGiffel, M.C., Beumer, R.R., Leijendekkers, S. and Rombouts, F.M. 1999. Incidence of Bacillus cereus and Bacillus subtilisin foods in the Netherlands. Food Microbiology 13 (1): 53-58.

38. Van Loo, I. H., Diederen, B. M., Savelkoul, P. H., Woudenberg, J. H., Roosendaa, 1 R., Van Belkum, A., Lemmens-den Toom, N., Verhulst, C., Van Keulen ,P. H. and Kluytmans, J. A. 2007. Methicillin-resistant S. aureus in meat products the Netherlands. Emerg. Infect. Dis.13(11): 1753-1755.

39. WHO "World Health Organization" 2007. Food Safety and Food-borne Illness, "Chapter 2 Food-borne Hazards", page 17-28.

40. Xavier, C., Gonzales-Barron, U., Paula, V.; Estevinho, L. and Cadavez, V. 2014. Meta-analysis of the incidence of food-borne pathogens in Portuguese meats and products. Inter. J. Food Res., 55: 311-323 